\title{
Strange Loops and a Cognitive Approach to Genre
}

\begin{abstract}
The following short paper will develop three ideas. Firstly it will explore whether a general theory of genre could make sense, following a cognitive approach. Secondly it will consider the cognitive value of the discussion about genre - thus attempting at a functional description of why it actually does make sense to think about genre. This part will include a critical reflection of the current state of the art - and an invitation to reconsider the need for genre awareness in the same sense as we discuss (or reject) the value and need for a canon. Finally we will propose a "strange loop" as a metaphor for genre, which allows both a systematic approach to genre and a historical openness for its development, thus combining identity and difference in a new dynamic concept.
\end{abstract}

CORRESPONDENCE: Peter Hanenberg. CECC, Catholic University of Portugal. EMAIL: hanenberg@fch.lisboa.ucp.pt. Per Aage Brandt. Department of Cognitve Science, Case Westem Reserve University. EMAlL: peraage.brandtgcase.edu

I.

The first idea is somewhat polemical. Why should it not make sense to develop a general theory of genre following a cognitive approach? One reason could be the general anarchy and the ubiquity of aporias (Neumann \& Nünning 2007: 1) in the theory of genre. Another reason could be the wide acceptance of cognitive constructivism and the consequent thesis of a non-ontological status of genre. In fact, genres do not exist before experience, and there is no proper life for them anywhere outside or in a heaven of etemal terms. And yet: genres do exist in experience, we talk about them, we give them names, and we develop theories for them. ${ }^{1}$ And even more puzzling: when we do so, we actually claim that genres exist before and beyond experience. Genre is not just the text that I read or the movie that I watch. It is more than that; genre precedes and goes beyond the singular case. This is especially true of the three main classes of genre that provide a certain basis or hyper-genre in literature: poetry, prose, and drama.

The next question would then be where poetry, prose, and drama come from, or - to elaborate the metaphor even further - where they are at home. In order to answer this question, we need to consider how knowledge and

1 Milan Kundera writes, in Encounter (2010, transl. Linda Asher): "If the future is not a value for me, then to what am I attached? To God? Country? The people? The individual?/My answer is as ridiculous as it is sincere: I am attached to nothing but the depreciated legacy of Cervantes." The Novel as such is Kundera's existential base. 
experience are organized and where in this organization genres arise as categories.

Figure 1 presents a simplified summary of the "Architecture of Semantic Domains", developed by Per Aage Brandt in Spaces, Domains, and Meaning (Brandt 2004). In the centre of the diagram we find the four basic semantic domains (the physical, social, mental and speech-act domains), surrounded by twelve satellite domains, organized in levels of progressive integration. In a first orbit we find the practical domains (work, love and worship). The second orbit is based on exchange and encompasses economy (exchanging things), jurisdiction (exchanging acts) and aesthetics (exchanging signs). The third orbit consists of discourse types - description, argumentation and narration - whose integration results in the three overarching domains of knowledge, namely science, philosophy, and history.

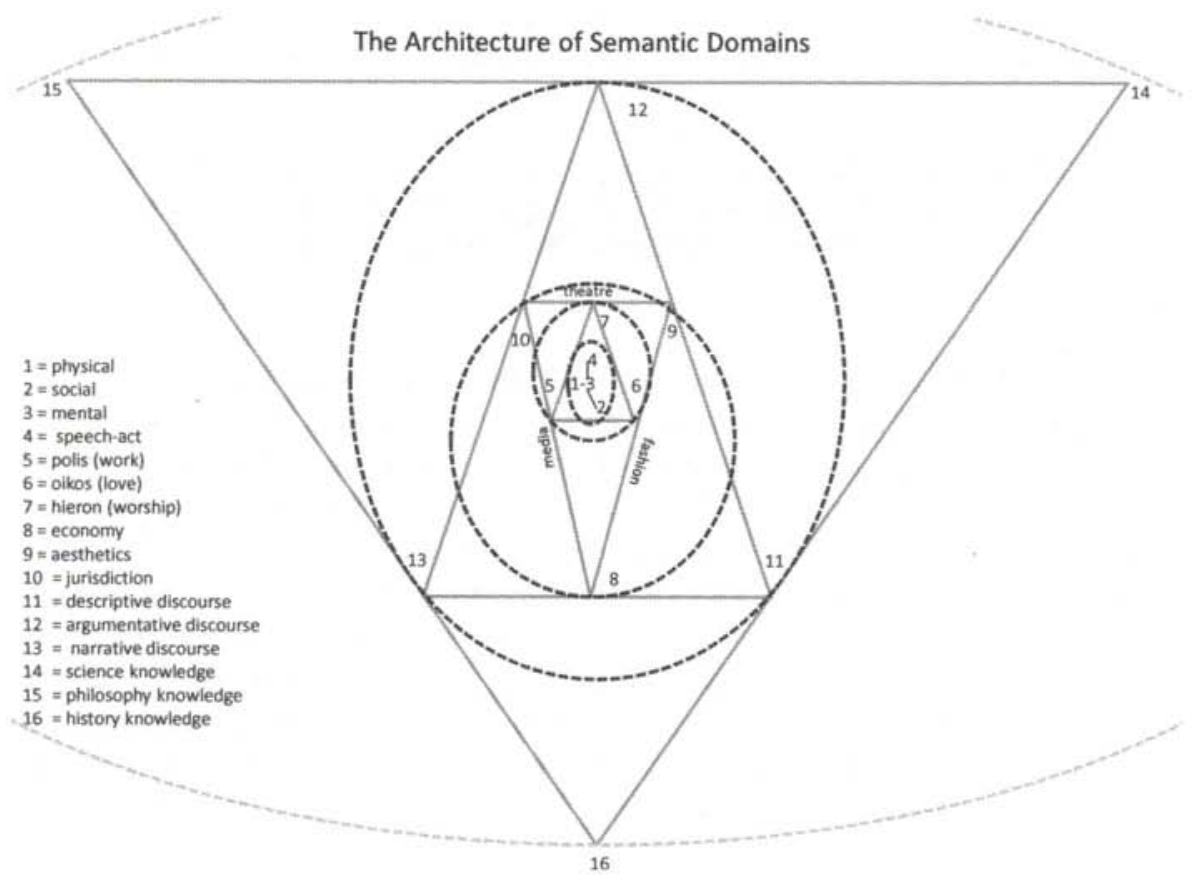

Figure 1. The semantic domains. Based on: Per Aage Brandt, Spaces, Domains and Meaning. Essays in Cognitive Semiotics. Bern etc.: Lang 2004.

It is not our purpose here to discuss this 16-piece architecture (four basic domains, four levels of satellite domains). Instead, we propose to use it in order to understand where poetry, prose, and drama are at home. This model provides two important hints, namely concerning prose and drama: it is perhaps uncontroversial to acknowledge that prose (fiction) is mainly at home in the narrative discourse and that theatre develops between jurisdiction and 
aesthetics, as a special way of exchanging acts and signs in the practical domain. As for poetry, we suggest that this genre is at home in an even more basic level, namely in the elementary domain of the speech-act itself, which reaches out to worship on the one hand and love on the other (Brandt 2004: 55; Figure 9). The result of such a description would be that the three main genres do not only pertain to different semantic domains, but also that they are at home on different orbits or levels of this architecture (the basic - poetry; the practical drama; and the discourse level - narrative).

This view reflects some basic intuitions. Namely that theater is 'staged poetry', and that story is 'framed theater'. Theatricality is a central social mode of communication, the one we need in order to transmit thinking (by playing the role of the thinker, empathically or ironically). Dialogue set up in narrative frames is of course more 'abstract' than performed dialogue, since it introduces an off-stage voice that carries the overall reflection and meaning-production of the events reported. Unstaged poetry is ubicuitous it happens every time language itself is foregrounded in the act of speaking or writing. So, in cognitive terms, it would be possible to venture that while the poetic mode is close to the individual speaker or writer (proximal and maximally embodied cognition), the theatrical mode is slightly less proximal, addressing and responding to the conventions of social roles and institutional behaviors (medially embodied, social cognition), whereas the narrative mode implies a reflective and overly critical distance to experience (distal, minimally embodied cognition).

On the other hand, this grounding of the genres on different levels of the architecture of semantic or experiential domains would explain why (at least linguistically) poetry appears to integrate into drama (verses becoming spoken lines, potentially), and why drama integrates nicely into narratives (stage comments becoming narrator's discourse). Whereas the inverse integration does not work. Discourse is domain-dependent. By contrast, language as such, grammatically, is in fact domain-indifferent; only vocabularies are domainspecific (or otherwise used metaphorically).

This would, finally, make it quite unlikely that a unique theory of genres could appropriately comprehend coherent descriptions and analyses of each of these. In this light, a general theory of genre might not make sense at all, or even be possible.

Of course there are several ways to object to this result. We might just discuss two of them. The first is that the architecture of Semantic Domains could itself be acknowledged as the common or general cognitive theory of genre. And, indeed, prose, drama, and poetry are within the architecture and thus within the theory. But if we would like to use this theory, we would have to recognize that prose, drama and poetry are just three elements in a wider number that makes up the architecture. In this sense it would not be sufficient to consider these three, but we should consider the other 12 domains as well and why should we give the status of genre to some domains and not to others? The Architecture of Semantic Domains is indeed a useful theory to see where 
our genres are at home, but it is not a sufficient theory to describe them as such. Nevertheless, the finding is more than nothing. We may now know where the genres 'come from' (before and beyond experience); and we know that the answer is not absolutely metaphorical: Different genres stem from different semantic and cognitive domains.

The second way to object to the thesis of the impossibility of a genre theory comes from the reader's experience. The reader might say: It is not true that prose just emerges from the narrative discourse; it is a speech-act as well and as such an exchange of acts and signs even in the dramatic sense. Or she might say: I know a lot of poems that are simultaneously narrative and dramatic; think of the rich tradition of ballads. Or he would argue: the common home of prose, drama and poetry is aesthetics. And of course, all arguments are true (in a sense) and fully related to concrete experience. But then we would have to ask: Is it not true as well that there are several types of speech acts, some requiring more involvement in the act itself (that means on its self-reference), while others focus on the debate of acts, and still others develop mainly a sequence of events (not to mention those which describe things, discuss arguments, negotiate business or pray to God)? And would this not be a reason to distinguish between them as genres?

II.

The first preliminary point we want to make is that a general theory of genre cannot be only a theory of genre. If genres are considered as "ways of worldmaking" (Neumann \& Nünning 2007: 6) we cannot describe and distinguish them without the context of other "ways of worldmaking" - and this turns the theory into a vast project of cognitive research. The second point is this: There seems to be no doubt that the study of genre is one of the key issues in the development of a coherent theory of cognition. Great work to be done.

Some suggestions have already been made on how to develop a historicalconcrete (and not a general) theory of genre, considering genre in its cultural construction more than in its cognitive foundation. Following David Rumelhart's theory of "schemata"2 as "building blocks of cognition", Janos Lászlo and Reinhold Viehoff suggested its application to genre theory, a proposal that has recently been exemplarily discussed by Wolfgang Hallet (Hallet 2007). The main idea is that genre works like schemata, "an instantiation of models we carry in our own minds" Jerome Bruner cited by Hallet 2007: 57). Schemata in this sense develop through categorization, or in the sense of

2 Please note that the notion of 'schema' is dangerously ambiguous. 1) Subcategorial schemata: A force-dynamic schema, for example, is a structural skeleton of a spatio-temporal microprocess that appears in many categories, in causation, modality, speech acts, etc. 2) Superrategorial schemata are higher-order gestalts involving a multitude of categories. A financial operation like 'investing', for example, implies and comprises rules, agents, institutions, etc. 
referring to a prototype as a set of schematic characteristics that 'characterize' good exemplars, though not all exemplars, of a category. Schemata allow certain recognition of actions and action plans. Peter Stockwell explains that schemata "have also been used to explain bundles of information and features at every level of linguistic organisation, from the meanings perceived in individual words to the readings of entire texts" (Stockwell 2002: 78); he clearly refers to supercategorial schemata (note 2). But these schemata are not just for understanding; they are productive in terms of conceiving action as well and then often called scripts. In this sense, Charles Fillmore proposes still another term for something close to schemata: He intends the word 'frame' as used "for the set of concepts variously known, in the literature on natural language understanding, as 'schema', 'script', 'scenario', 'ideational scaffolding', 'cognitive model', or 'folk theory'." (Fillmore 2006: 373).

It is quite clear that the notion of supercategorial schemata or 'frames' would work in the conception of genre. Novels, dramas, and poems imply internal and external ingtedients and circumstances: what can go into such texts, and how they can be adequately 'used' in cultural life. For example: Poetry is a frame - in the sense that it takes a poet, a critic, a reader, a writers' union, a publisher, etc.

However, if we follow Hallet and say that frames, or supercategorial schemata work in the conception of genre, of course we do not want to say that genres are just that. There is something more about genre than that. There is the artistic experience, the singularity of every work of art, the beauty, horror, and deep feelings involved, because these things are about life. And life is not a frame (unless the frame of all frames is a frame).

Neumann and Nünning (2007: 4) refer to a sentence written by Peter Stockwell as not being very encouraging. "Genre can be defined socially, historically, functionally, authorially, politically, stylistically, arbitrarily, idiosyncratically, or by a combination of any of these" (Stockwell 2002: 28). The point is that genre as a schema will have to refer to all processes and domains that work in it, in order to make sense of a set of events. So, 'schema' in this sense is a relational or rather, dynamical term, not a static, frozen class, defined by criteria - and therefore necessarily under change in a manifold of ways. The categories and subcategorial schemata that a genre is referring to at a given time cannot just be found in one cognitive process, so that we could identify a genre just by a list of features. Integrating phenomena belonging to many different domains and referring to special discourses (as in speech or texts) or even to highly specialized discourses, genres are entities of a very high complexity and inseparably related to particular instances and - to life itself.

So, at a first glance, supercategorial schemata seems to be a viable solution to define what a genre is about, and in fact, a simple model of such a schema seems to be a quite reliable way of describing and predicting what happens in a specific case - let's say when we consider three basic elements, like action, agents and social reference, text length, rhyme structure, verse form and topic. 
Then we get a predictable schema that works out consequently - like a tick-tactoe: we are sure we will never lose (that is, we know how the genre can be 'defined'). But imagine now that you take some more possibilities into account, let's say like in chess; then suddenly for each move you find some thirty possibilities, "which makes $30^{20}$ (thirty raised to the power of twenty) sequences in twenty moves, amounting to some 350.000.000.000.000.000.000.000.000.000 [ 350 nonillions] possible sequences of moves" (Gigerenzer 2007: 88f.), and thus hardly to be foreseen. Beauty is in singularity.

The point is that we do not give up playing chess because of that - on the contrary, we gave up tick-tac-toe a long time ago for being boring. That is exactly what happens in genre theory. Thus, Wolfgang Hallet refers to the dynamic and tentative character of genres, given in the altemate ways of writing and reading and hence concretizing abstract schemata in a constant mix of a wide range of possibilities.

Let us just add one more possibility to the huge number of possible sequences of moves: We can use the chessboard not just for playing, we can use it as a basis - let's say - for cutting bread. Suddenly, all the different moves in playing chess on the chessboard turned out to be of the same kind, compared to cutting bread on it. Cutting bread is not a possible move in chess playing, but it is a possible move for our use of chessboards. It may be shocking for chess players but it is far from shocking for hungry people. And we - in between - have a schema for both, just transferring one to the context of the other. Of course, the example seems to be extreme - as extreme as Duchamp's first ready-made in the New York exhibition 1917. But it clearly shows that framing schemata - even admitting a nearly unlimited range of possibilities - never can be considered a safe harbour of silent affirmation of their predictability.

By explaining this, we gain another insight in genre. Genre is not just controlled by a certain number of moves (to continue with the language of chess) within the frame, but also by the openness of its possibilities. Telling always the same story is not a genre at all (Hogan 2003: 70ff.) - it is a boring repetition of a single case. Genre counts on diversity within a certain structure of possibilities. Without this common structure it would be just nonsense or noise. Chess is a possible world' with a certain (and huge) number of moves allowed in it. Cutting bread on the chessboard is not within this possible 'world'. In this sense, genres are bound to certain possible 'worlds' (and certain possible words) defined by the underlying frame.

On a higher level than things, animals, tools, etc., genres are again categorized, and categorization (Eleanor Rosch et sq.) is radial out from a prototype, it can thus have extremely fuzzy boundaries without being inconsistent." This contrasts with the Wittgensteinian view of 'family

3 A radical view along these lines was held by the great Danish scholar Knud Togeby, who used to explain to his students that a genres is (nothing but) a masterpiece plus its epigonal 
resemblance', as much as it contrasts with the view that notions are 'defined' by criteria in human cognition (only artificial notions, neologisms, such as technical terms, are constituted this way, by explicitly defined criteria). Categorization is not 'definition' at all; neither is genre constituted by definition. Rules, if genres can indeed be described as different by different sets of rules, are not just criteria or features, but instead structural properties rooted in semantic ontology. ${ }^{4}$ They can be implicit, or be explicitly staged as commonly recognized genre signatures.

In the sense of patterns that function as genre signatures, today's artists do not stick to rules demonstratively like former generations did. The first bourgeois in a high tragedy was as revolutionary as the first descriptions of morgues, hernias, and coffee machines in poetry. But the idea of genre still counts on certain ways of connecting things. Two problems derive from that. First: Sometimes literary scholars would like to go back to ancient times - and feel safe, where uncertainty is adequate. Thus, Wolfgang Hallet tries to introduce a difference between "cognitive schemas before science" and others called "cognitive schemas in science", replacing their intuitive use by empirical proof, and their occasional appearance by systematic development and a socalled subjectivity by "objectivation" (Hallet 2007: 67). We would like to doubt whether he is on the right track. It is not likely to be the case that our cognition is divisible in a scientific part and a pre-scientific part. How would we separate them? When does one start and the other end? So we will have to protest against the idea that "cognitive schemas before science" are subjective. Framing schemata are culturally transmitted and thus intersubjective by definition as well as constrained at a deeper level by the conditions of human cognition as such (i.e. not subjective or idiosyncratic). A framingschema that is not being shared is not a schema at all. ${ }^{5}$

From a cognitive point of view the aspect of sharing is crucial - both in the construction of meaning and in learning. It is through a common set of frames (rules, patterns norms) that a culture emerges. Hence, the question of genre is not just an academic issue but is closely related to the acquisition, the exercise and the imparting of culture. What would happen, if 'genre' became an arbitrary term that made no difference and hence did not contribute to the constitution of meaning at all? And what would happen if a complex and sophisticated system of genres were not shared by cultural experience? In both cases, genre would lose its cognitive value - and thus cognition would lose a way of making sense of certain events. Consider that if someone does not know when

echoes. Such a 'masterpiece' would count as a prototype, and other tokens of the genre that it creates would count as more peripheral exemplars.

4 The notion of 'rule' is not simple either. Wittgenstein interestingly commented that it is in principle impossible to know if a rule is followed, unless we introduce another rule, and so on. The interpretation of written laws raises the same problem, which is only solved in 'practice', namely socially.

5 Of course, this is also, and in an even stronger sense, true of subcategorial schemata. These are constitutive of cognition as such. 
something is poetry (as a characteristically self-referring speech-act), then such a linguistic event must seem nonsense to him.

Or imagine - on the other hand - that in a sophisticated system you are exposed to a genre called 'eco-ballad'. You will be happy if you recognize that the schemata of ecology and ballad merge together in something that you are already comfortable with. It seems quite unlikely to us that you will redefine your schema of ballad (and even less your schema of ecology) due to the labelling of the new so-called genre. Hence, an eco-ballad genre would hardly make much sense from a cognitive point of view. Wolfgang Hallet finds in the "creative genre-labelling" (65) a fascinating challenge for literary studies. We might ask, though, if there is any use of it before one knows about ballad at all. Or about poetry itself. While never having read any eco-ballad, we can easily imagine what it would be. From a cognitive perspective it does not make much sense directly and in itself, but we can easily blend the components called upon in our mind.

Therefore, one of the things we need to understand is the real potential or force offered by certain genres to those who conceive and perceive them. Leonard Talmy has developed a theory of 'ception' "to cover all the cognitive phenomena, conscious and unconscious, understood by the conjunction of perception and conception" (Talmy 2003: 139). As a matter of 'ception', some genres are mostly at the low end of palpability, often experienced as being nonmanifested, implicit or abstract. Others are 'ceived' as concrete, manifest, explicit and even countable (if you think of the number of verses in a sonnet). Within the thirteen parameters for 'ception' presented by Talmy, the parameters of certainty (and mainly its low end as doubt) and stimulus dependence (and once again its low end in the absence of concrete stimulus) seem the most relevant ones to describe the cognitive challenge of genre. Trying out to measure exactly what a genre is, we might reclaim a metaphorical application of Heisenberg's "Uncertainty principle". However, a cognitive approach to genre would look for those stimuli that bring up the 'ception' of its actuality: In which sense do mathematics and music (or aural stimuli) meet in a sonnet? Which cognitive process results from an 'urban novel'? Which in the case of a soapopera? The underlying schemata may be comprised of numerous and divergent stimuli and elements, and thus we follow some intuitive rules of thumb in the 'ception', sometimes with more, sometimes with less certainty. What are we 'ceiving' in each case? And how does the generic framing - the schematization by genre, of the perceived - affect our making sense of the experience? It is evident that it does.

Talmy's 'ceptivity' is a variation on the vertical relation between 'top-down' and bottom-up' processes of interpretation. Since it has to instantly work in both direction, we think that in terms of process, we need to see it as a loop. 
From the point of view of a history of genre, we recognize a 'dialectic's movement: on the one hand, there are bottom-up forces generalizing the Gestalt forms originated in the singular masterpieces: So, any masterpiece may create its epigones, and from the point of view of the epigones it creates, it constitutes a historical network, which may be the germ of a 'genre' (cf. note 3 ). But on the other hand, the top-down forces also are active; they distinguish forms that originate in different enunciation structures: poetry is basically I SAY [...] (enunciating enunciation), whereas drama is: HE SAID [...] SHE SAID [...] (enunciated enunciation), and story ( $=$ fiction) is: I PRETEND TO BE SOMEONE WHO TELLS YOU WHAT HAPPENED (the narrator is a theatrical observer or reporter role played by the real enunciator - even if that role is impersonal; this creates 'fictionality'). Top-down meets bottom-up halfways, and we get the historically existing gentes. In 'ception', ascendent forces (bottom-up) meet descendent forces (top-down), and we get a halfempirical, half conceptual 'cept' [...]. When the hypercategorial schema meets the structures of the singular phenomenon, we get the significant object - such as: a poem, a story, a drama; a limerick, a joke, a farce; etc.

There are a lot of urgent questions left here. A cognitive approach to genre should not just explain a particular genre as such, or a system of genres. It should also explain the reason for the use of given genres in textual and contextual 'ception'. This seems to be an extremely important challenge, even as it means to sacrifice - in a certain sense - a more literary and systematic approach. So: why is there poetry? When and where do people 'do' poetry? would be the question to ask. Why, where and when do people tell stories? Why, where, when do people dramatize? Such questions suggest that the literary uses are not constitutive, but rather that a certain aesthetization of more fundamental semiotic practices takes place.

6 This movement is 'dialectic' in the sense of existing-in-change, but not in the sense of moving in a specific direction (like: from primitive to evolved...). 


\section{III.}

To conclude this brief reflection, we would finally like to illustrate the first part of the paper's title: a strange loop.

\section{A given genre is a conflict between a generic concept and singular percepts}

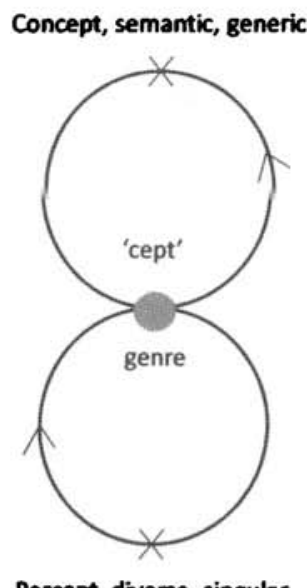

Percept, diverse, singular

Figure 2. The 'ceptional' loop.

This loop is intended to describe both the way we read and the way we write a text, in both cases through a process connecting the singularity of the materialized expression and the supercategorical identification, or genericity, of the abstract entity to which it is cognized or 'ceived' as (more or less) 'belonging'.

'Ception' does not need hard and palpable entities to occur. On the contrary, most categories and supercategorial entities are defined by its high end as well as by its low end: think of a penguin as being a bird or a chessboard as a bread-cutter-basis. What is in a genre cannot be counted or listed as criteria, and still we never abstain from its use. We have to imagine each genre as a continuous act of perceiving and conceiving where the egg of primitive outcome and the culmination of its potentiality coincide. Paraphrasing Douglas Hofstadter, we might define a genre as "the vast episodic memory of its past, together with its counterpart pointing blurrily towards what is yet to come, and further embellished by a fantastic folio of alternative versions or subjunctive replays of countless episodes, [that] gives rise to the endless hall of mirrors" (Hofstadter 2007: 181) that is constitutive to it. Imagining each genre as a "strange loop" of continuous reflection and critical self-reflection, we find a way to discover genre not as a static system but as a dynamic 'cept'. The benefit 
of this view may be considerable: the retrieval of its real semantic and experiential relevance. We then could start to analyse genres as socio-mental sets whose semiotic functions would intimately be related to their signifying forms. Appearance and meaning would be connected not by an artificial exercise but in a continuous attempt to explore old, new, and invariable ways of textual cognition.

\section{Adendum}

Here is a historical example from the field of poetry: modemity has seen a 'revival' of the sonnet. This poetic genre, emerging in the early Italian renaissance (Giacomo da Lentini, Guittone d'Arezzo), spread over Europe and unfolded in all Renaissance, Baroque and, later, Romantic literatures. When free verse became the modernist emblem, it would be expected to disappear as a plausible 'contemporary' form of expression. But surprisingly, and exceptionally, it survives in different shapes, all perfectly direct - as opposed to pastiche exercices - and genuinely modern:

1. Jorge Luis Borges: El otro, el mismo, Buenos Aires: Emecé, 1964.

A quien ya no es joven

Ya puedes ver el trágico escenario

Y cada cosa en el lugar debido;

La espada y la ceniza para Dido

$Y$ la moneda para Belisario.

¿A qué sigues buscando en el brumoso

Bronce de los hexámetros la guerra

Si están aqui los siete pies de tierra,

La brusca sangre y el abierto foso?

Aqui te acecha el insondable espejo

Que soñará y olvidará el reflejo

De tus postrimerias y agonias.

Ya te cerca lo ultimo. Es la casa

Donde tu lenta y breve tarde pasa

$Y$ la calle que ves todos los días.

An anti-heroic and anti-hexametric call to decasyllabic everyday concerns that share the regularities of the verse form. 
2. Vasco Graça Moura: Sonetos familianes, $2^{2}$ ed. Lisboa: Quetzal 1999.

pax rustica, uma ironia

atravesso o pinbal $O$ men cão salta.

fulvo tigrado ele é da cor do mato.

por entre o tojo escapuliu-se um gato

e liga as copas uma nuvem alta.

evito a Estrada e o seu trajado exacto

que a lentidão municipal asfalta.

antes o cimo em que o pulmão se exalta

e as pinhas vêm à ponta do sapato.

restolbo e urze, giestas, estalidos

de follhas secas, água a correr, ruidos,

vozes distantes chamam dos quitais.

já o sol vai a pino, já no ermo, como a manhã, todo o prazer tem termo:

chegado ì vila, vou comprar jornais.

Buying newspapers in the last line of a sonnet is again to build a relaxed hynn to triviality, this time with a certain tendemess.

3. Jacques Roubaud, E: poems. Paris: Gallimard, 1967.

Sonnet en prose

Je ne vois plus le soleil ni l'eau ni l'berbe m'étant emprisonné où nul matin n'a de domaine si dans le cube pur de la nuit je distingue d'autres branchages que sur l'arche des pensées je les chasse je les cache n'ont de place que les lampes la division du clair au sombre au devant de moi coupant le visible le peu de monde materiellement étendu à plat oui devant moi accessible partout à mes mains

car tous objects d'ici disparus j'ai suscité soleil pour soleil eau pour eau j'ai fait traverser des monceaux d'opaque à des soleillements d'ailleurs 0 soleils en qui j'ai confiance à quel point vous êtes moi je peux vous montrer à tous dire couleur des bois orange dire rouge et être cru soleils réveillés sur ma langue soleils alentour-averses 
This is hardly a sonnet in prose but it certainly is not in verse either; the graphic properties of the page are recruited for formal reasons; rhyme and meter are gone, but the stanzas stay alive. The genre remains active - albeit at a distance.

5. Ulla Hahn: Herz über Kopf. Gedicbte. München: Deutsche Verlags Anstalt 1981.

\author{
Anständiges Sonett \\ Schreib doch mal \\ ein anständiges Sonett \\ ST.H.
}

Komm beiß dich fest ich balte nichts

vom Nippen. Dreimal an Anfang kïß

mich vo's gut tut. Miß

mich von Mund zu Mund. Mal angesichts

der Augen mir Ringe um

und laß mich springen unter

der Hand in deine. Zeig mir wie's drunter

geht und drïber. Ich schreie ich bin stumm.

Bleib bei mir. Warte. Ich komm nieder

zu mir zu dir dann auch

"ganz wie ein Kehrreim schöner alker Liederw.

$V$ erreib die Sonnenteringel auf dem Bauch

mir ein und allemal. Die Lider

balt mir offen. Die Lippen auch

Ulla Hahn reintroduces two other elements from the tradition in her poem: first the rhyme schema - frequently absent in other poems written by the German author. Significantly the rhyme goes totally against the natural flow and sense of words, skipping the lines by surprising breaks which cause a kind of inaudible rhyme. Secondly she recovers the Petrarchian tradition of using a sonnet to present the ideal attributes of a female body in a description reaching (in this case) from the mouth to the belly. The title of the poem invites to a reflection on its "property" as a "decent" sonnet.

6. In The London Review of Book, 5 August 2010, a reader, S. J. Silverman, brings forth this anonymous perfect monometric epistolar sonnet, which we will reproduce without comments: 
An Aeronaut to His Love

I

through

blue

sky

$f y$

to

you.

Why?

Sweet

Love,

feet

move

so

slow.

\section{References}

Brandt, Per Aage (2004): Spaces, Domains and Meaning. Essays in Cognitive Semiotics. Bern etc.: Peter Lang.

Fillmore, Charles F. (2006): Frame semantics, in: Cognitive Linguistics: Basic Readings, ed. Dirk Geeraerts, Berlin: de Gruyter, 373-400 (first 1982).

Gigerenzer, Gerd (2007): Gut Feelings. The Intelligence of the Unconscious. London: Viking.

Hallet, Wolfgang (2007): Gattungen als kognitive Schemata: Die multigenerische Interpretation literarischer Texte, in: Gattungstheorie und Gattungsgeschichte, hg. Marion Gymnich, Birgit Neumann \& Ansgar Nünning. Trier. wvt, 53-71.

Hofstadter, Douglas (2007): I am a Strange Loop. New York: Basic Books.

Hogan, Patrick Colm (2003): Cognitive Science, Literature and the Arts. A Guide for Humanists, New York and London: Routledge.

Neumann, Birgit \& Nünning, Ansgar (2007): Einleitung: Probleme, Aufgaben und Perspektiven der Gattungstheorie und Gattungsgeschichte. In: Gattungstheorie und Gattungsgeschichte, hg. Marion Gymnich, Birgit Neumann \& Ansgar Nünning. Trier: wvt, 1-28.

Rumelhart, D.E. (1980). Schemata: The building blocks of cognition. In R. J. Spiro, B.

C. Bruce, and W. F. Brewer (Eds.), Theoretical Issues in Reading Comprebension (pp. 3858). Hillsdale, NJ: Lawrence Erlbaum Associates.

Stockwell, Peter (2002): Cogritive Poetics. An introduction, London, New York: Routledge. Talmy, Leonard (2003): “Ception": Generalizing over Perception and Conception. In: L. Talmy: Toward a Cognitive Semantics. Vol. I, Cambridge (Mass.): MTT, 139-168. 